This item was submitted to Loughborough's Research Repository by the author.

Items in Figshare are protected by copyright, with all rights reserved, unless otherwise indicated.

\title{
A model of discourse in action
}

PLEASE CITE THE PUBLISHED VERSION

http://dx.doi.org/10.1177/0002764293036003008

PUBLISHER

(c) SAGE Publications

VERSION

AM (Accepted Manuscript)

LICENCE

CC BY-NC-ND 4.0

REPOSITORY RECORD

Potter, Jonathan, Derek Edwards, and Margaret Wetherell. 2019. "A Model of Discourse in Action”. figshare. https://hdl.handle.net/2134/9427. 
This item was submitted to Loughborough's Institutional Repository (https://dspace.lboro.ac.uk/) by the author and is made available under the following Creative Commons Licence conditions.

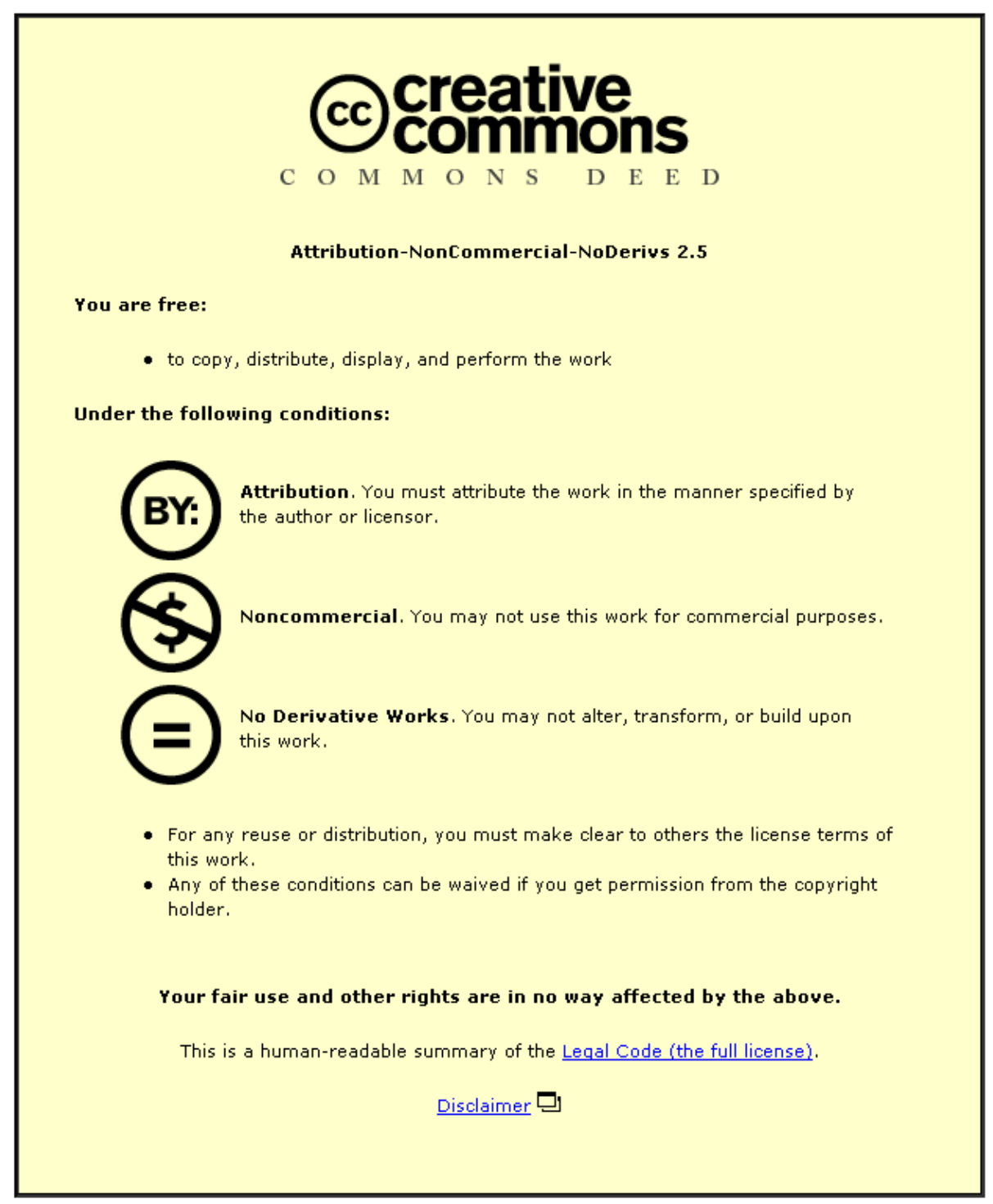

For the full text of this licence, please go to: http://creativecommons.org/licenses/by-nc-nd/2.5/ 


\title{
A Model of Discourse in Action
}

\author{
Jonathan Potter $^{1}$, Derek Edwards ${ }^{1}$, Margaret Wetherell ${ }^{2}$
}

1 Discourse and Rhetoric Group,

Department of Social Sciences,

Loughborough University,

Loughborough,

Leicestershire, LE11 3TU, UK

Tel: 0509223384

Fax: 0509238277

J.A.Potter@uk.ac.loughborough

D.Edwards@uk.ac.loughborough

2 Faculty of Social Sciences,

Walton Hall,

Open University,

Milton Keynes,

MK7 6AA, UKMarch 1, 2012 
Jonathan Potter is Reader in Discourse Analysis at Loughborough University Department of Social Sciences. He has published numerous articles on fact construction and the relation between discourse and psychology. He is the author of Discourse and Social Psychology (Sage, 1987, with Margaret Wetherell), Discursive Psychology (Sage, 1992, with Derek Edwards) and Mapping the Language of Racism (Harvester/Wheatsheaf, 1992, with Margaret Wetherell). He is associate editor of Theory and Psychology.

Derek Edwards is Senior Lecturer in Social Psychology at Loughborough University Department of Social Sciences. He has published numerous articles on discourse, cognitivism and knowledge. He is the author of Common Knowledge (with Neil Mercer), Discursive Psychology (Sage, 1992, with Jonathan Potter). He edited Collective Remembering (Sage, 1991, with Dave Middleton). He is associate editor of Papers in Pragmatics and Memory.

Margaret Wetherell is Lecturer in Social Psychology at the Open University. She has published numerous articles on discourse, racism, and gender. She is the author of Discourse and Social Psychology (Sage, 1987, with Jonathan Potter) and Mapping the Language of Racism (Harvester/Wheatsheaf, 1992, with Jonathan Potter). She is associate editor of Feminism and Psychology. 
In the last fifteen years or so a number of varied strands of research have been dubbed 'discourse analysis': speech act orientated studies of conversational coherence (e.g. Coulthard and Montgomery, 1981); so called 'discourse processes' work on story grammars and the like (e.g. van Dijk and Kintch, 1983); the 'Continental' discourse analysis of Foucault (e.g. 1971), which has been concerned to show the way different cultural entities are constituted discursively as well as the historical development of that constitution; and finally specific developments within the sociology of science which arose in part as a consequence of methodological debates on the role of discourse in research methods (e.g. Gilbert and Mulkay, 1984). The approach we have developed (Edwards and Potter, 1992; Potter and Wetherell, 1987; Wetherell and Potter, 1988) draws on important features of both the Continental and the sociology of science work; although it is also strongly influenced by developments in conversation analysis (e.g. Atkinson and Heritage, 1984) and rhetoric (e.g. Billig, 1987). It also emphasises the centrality of constructionist processes (Gergen, 1985); and this is a facet of discourse analysis we will develop further in the current chapter.

At its most basic, we see discourse analysis as being theory of, and method of studying, social practices and the actions that make them up. As such, it offers an alternative to the cognitivist paradigm dominant in general psychology and the specific social cognition paradigm of social psychology. Over the last few years part of the energy of discourse analysts has been devoted to showing how the central theoretical notions of cognitivism - e.g. remembering, attribution, categorization - can be reworked in discursive terms. This reworking, in turn, raises important questions about the way these notions are understood within the context of more traditional cognitivist approaches. Indeed, for this reason, and to combat interpretations which take discourse analysis simply as a method which can be 'plugged in' when answering questions developed using the assumptions of alternative 
approaches, we have suggested that discourse analysis can form the basis of a distinctive discursive psychology (Edwards and Potter, 1992a). Yet we must also stress our qualified sense of the notion of psychology here. Although this is an approach which reworks basic psychological phenomena it has also been directed at themes and topics more commonly seen as the province of communication, cultural studies and sociology (Billig, 1992; Wetherell and Potter, 1992). The aim is certainly not to replace one psychology of individuals with another.

This chapter will overview this discursive approach to psychology in two stages. First, we will outline some of the basic ontological commitments of cognitivist psychology (either 'pure' or social), showing some of the difficulties that discursive psychology raises for them. These stem, we will argue, from a failure to adequately conceptualize the central role of 'factual versions' (reports, descriptions, representations, etc.) in social life. Second, and for the greater part of the chapter, we will overview a model which integrates together various discursive phenomena, indicating general areas of research support.

\section{Mind - Identity - Reality: Some ontological commitments questioned}

Much mainstream cognitivist psychology works more or less explicitly with a threefold ontology of identity/personality, mind and reality. This can be represented as follows:

\section{Identity/personality}

There is an actor who has a range of defining features: a personality, a self or identity, and possibly a range of commonly available roles. 
$\underline{\text { Mind }}$

Within the actor are a variety of entities that are basic to the explanation of behaviour: attitudes, attributional schemata, category systems, memories, social representations and so on. These are treated as cognitive processes or mental events, and together they largely make up what psychologists gloss as mind.

\section{$\underline{\text { Reality }}$}

The actor is construed as acting in some environment, the world, the situation, context. This may comprise of other people, social settings or various physical objects and events.

Having accepted these assumptions, the orthodox psychological task is to discover what is going on in the first two of these realms which are opaque areas needing to be penetrated. Psychologists attempt to elucidate characteristics of the person, or their identity; or alternatively, and more commonly now, to identify features of mind: cognitive entities or processes. Often these two realms are treated as interdependent. In contrast, the third realm, reality, is treated as unproblematic, something that the researcher has clear access to and can be used as a criterion against which to measure the behaviour of subjects. For example, in the typical memory study the adequacy of memory, the pattern of 'distortion', or whatever, is compared against the actual 'stimulus materials' or against 'what actually happened'. Or, in the typical attribution study, the sense of vignettes is treated as transparent to the researcher, who is concerned about inferences made by participants. Moreover, it is notable that in each of these cases textual materials of one kind or another are taken as a stand-in for events or persons. They presuppose that the world is simply and neutrally represented in texts. 
One of the features of discursive psychology which distinguishes it from cognitivist approaches is that it questions the simplicity and neutrality of rendering the world into versions as well as the assumption of epistemological privilege that goes with it. The argument can be made on both conceptual and analytic grounds. There are a variety of conceptual arguments about the nature of description which stress the indefiniteness or open endedness of descriptions, the varied ways in which scenes or events can be formulated, and the impossibility of producing a single definitive version free of interests or perspective (e.g. Kuhn, 1970; Popper, 1959; Wittgenstein, 1953). The point here is given the open-endedness of any description, why should the psychologist choose one particular one as unproblematically correct for comparison with participants' partial versions?

The implications of these conceptual arguments in practice can be seen from the range of work on the practical nature of description and the role of reports or formulations in specific interactions (e.g. Drew, 1984; Heritage and Watson, 1979; Pomerantz, 1987; Schegloff, 1972; Wooffitt, 1992). The important point from this work is that description as a participants' activity is not merely open ended and flexible, but also an important way of performing actions. For example, Pomerantz (1980) shows the way specific sorts of descriptions (those displaying partial knowledge in contexts where the recipient has full knowledge) are used for performing delicate actions such as eliciting an invitation to a party or remaking a broken doctor's appointment without being heard as complaining, as in the following:

Desk: $\quad$ Hello $G$

Janet: $\quad$ Ehm good mohrning. eh it's Missiz

$R \_$heuh, I ca:lled in on

Thuhrsday: tih see: if uh I c'd 
make en appointment t'see

Mistuh $T$

Janet: $\quad$ An, I haven't huhrd anything'n I

wz wondring if: uh:m I c'd possibly

see im one day next week.

(Pomerantz, 1980: 193)

Pomerantz notes here the way the caller tells just what she knows without formulating items that are a possible source of complaint.

The point of these arguments, then, is to show, first, that there is an open-endedness to description which means that when a psychologist opts for a particular version they are assuming a kind of epistemological privilege (taking, without justification, one version as more correct than potential alternatives) and, second, that the choice of version may be a highly consequential matter for participants. A particular description, a particular style of description, the use of particular terms, and so on may be precisely the way a specific action gets done. By choosing one version rather than another psychologists can be siding, without realizing it, with one argumentative position rather than another or with some participants rather than others. That is not to say that participants themselves do not at times treat descriptions as straightforward - yet this very straightforwardness in description can itself be analysed as an outcome of participants' practices: doing a 'straightforward description' can be a way warranting a version as factual: merely 'telling it how it is' (cf. Edwards and Potter, 1992a; Potter and Edwards, 1990). 
The failure to make problematic the epistemological status of versions is part of a more general lack of concern on the part of psychologists with factual versions and their role in social life. It is striking, for example, that there is virtually no social psychology of fact and description; and what moves there are in this direction - most notably in the fields of social representations (Moscovici, 1984) and the psychology of knowledge (Kruglanski, 1990) tend to start from precisely the assumption of epistemological privilege we have been questioning.

To summarise, then: we have put the case for taking the 'reality' or context of action to be something constructed by participants in the course of their social practices and not something that should be legislated by the researcher without consideration of those practices. Our response to this issue is to take factual discourse as one of our central research topics. This involves studying the way particular versions (reports) are made to appear factual and independent of speakers or writers and - equally importantly - investigating the different activities that can be done with factual discourse. The form that such research would take is developed later in this chapter.

So far in this section we have focussed discussion on the third ontological realm of cognitivist psychology: reality. Having made this argument, we can follow its consequences through for the way psychologists deal with the other two basic realms in their ontology: identity and mind. In everyday life one of the central themes of people's talk is their 'inner life'; their thoughts, feelings, attitudes, goals etc.; another is their own and, perhaps more commonly, others' identities: what certain people are like, their foibles, defects, charms and so on. One of the features of this talk, of course, is that it is full of descriptions, representations and factual claims of one kind or another. That is, much of it is the same kind of talk as we have 
already discussed with respect to the way versions of reality are constructed. Indeed, for participants the contents of mind and what people are like is as much part of their local realities as whether the threat of nuclear war has been reduced or whether they have been invited to Saturday's party. This means that the same arguments apply in these two realms as in the realm designated external 'reality' (Coulter, 1979, 1989; Harré, 1983; Peräkylä and Silverman, 1991).

Here too, versions can be constructed to do particular kinds of activities. For example, a person may offer a description of their motives in the course of declining an offer which lessens hurt and displays sympathetic understanding (Drew, 1984; Heritage, 1984). In this case the S's wife has just slipped a disc:

$\mathrm{H}: \quad$ And we were wondering if there's anything we can do to help

S: $\quad$ Well 'at's

H: I mean can we do any shopping for her or something like tha:t?

S: $\quad$ Well that's most ki:nd Heatherton .hhh At the moment no: because we've still got two bo:ys at home. (Heritage, 1984: 271)

$\mathrm{S}$ here constructs the motive for rejection in terms of a description indicating lack of necessity rather than suggestion that she does not want help or the offer is not appreciated. It is important to stress here that the suggestion is not that people are simply being strategically 
manipulative or deceptive here - the analysis is agnostic with respect to issues of 'planning' or 'real motive' (cf Heritage, 1990/91). It is not trying to slip some common sense cognitivism in through the back door.

The point is that once we embark on this line of thinking it becomes difficult to sustain a strong distinction between the three realms of mind, identity and the world. The consequence of starting to address constructionist processes in the first realm is that we can quickly see them at work in all three of these areas. Furthermore, we can start to see complex patterns of inference between them in ordinary talk. For example, people can construct versions of how the world is, which will warrant a version of something that has gone on in their mind; that is, a particular version of how some event happened can be the basis for the current speaker's motive. A version describing in detail another's exploitative actions displays a motive for being cross with that person (cf Mills, 1940).

The general upshot of this type of reasoning has been to breakdown the basic ontological divisions assumed in psychology between mind, persons and reality. All these things are reworked in terms of their constructed versions in discursive practices. Indeed, not only is this ontological divide broken down, but the standard subdivisions between different kinds of psychological inquiry start to become increasingly problematic. Psychological and social psychological concepts become reworked as parts of a range of discursive practices, throwing up the possibility of complex interrelationships and putting into question some of the discrete process models which have been one of cognitive psychology's most important legacies over the past two decades. To see this latter point more clearly we will overview and build on a model of discourse in action (Edwards and Potter, 1992a, 1992b). 


\section{$\underline{\text { Discourse in Action }}$}

The 'Discursive Action Model' (DAM) is designed to link different features of participants' discourse together in a systematic manner, paying particular attention to workings of these features in participants' social practices. At the same time, this model emphasises

connections between psychological concepts previously kept separate. Mind, identity and reality all enter into the model - but as matters of representation, not things in themselves. It is not a process model in the more customary cognitive psychological sense; that is, it does not link together putative mental operations to show how input is transformed to a different output. Indeed, it is not an individualistic model at all. On the one hand, it refers to discourse that may be the product more than one person (e.g. newspaper reports), that may be produced interactionally (e.g. John Dean's testimony) and without any necessity for conscious planning; on the other, it captures features of participants' descriptions which refer to subparts of actors ('he was struggling with his conscience') and broad collectivities ('the middle classes don't understand poverty') as well as individual actors. It is an attempt to specify some of the central features of the way people's discourse is organized in the conduct of social actions.

The model id divided in to nine subparts organized broadly into three themes: action, fact and interest, and accountability. We will start by baldly listing them and then go on the flesh out the parts in more detail. 


\section{DISCURSIVE ACTION MODEL}

\section{ACTION}

1. The research focus is on action rather than cognition or behaviour.

2. As action is predominantly, and most clearly, performed through discourse, traditional psychological concepts (memory, attribution, categorization etc.) are reconceptualized in discursive terms.

3. Actions done in discourse are overwhelmingly situated in broader activity sequences of various kinds.

\section{FACT AND INTEREST}

4. In the case of many actions there is a dilemma of stake or interest, which is often managed by doing attribution via factual reports and descriptions.

5. Reports and descriptions are therefore constituted/displayed as factual by a variety of discursive devices.

6. Factual versions are rhetorically organized to undermine alternatives.

\section{ACCOUNTABILITY}

7. Factual versions attend to agency and accountability in the reported events.

8. Factual versions attend to agency and accountability in the current speaker's actions, including those done in the reporting.

9. Concerns 7 and 8 are often related, such that 7 is deployed for 8 , and 8 is deployed for 7. 
Counter to the current trend to increasingly cognitivist explanations in psychology, this model is focused specifically on action; and overwhelmingly action done through discourse (DAM Point One). This does not mean, however, that it is simply marking out some new research territory, nor is it proposing merely a new methodological orientation - although it is undoubtedly doing both of these things. One of our main aims has been to show how phenomena previously understood in cognitivist terms can fruitfully be reconceptualized as parts of a discursive psychology.

In the light of our discussion above about the importance of the constructed and open-ended nature of versions of 'reality' it is notable that many of the central concepts that make up the theoretical discourse of psychologists are representational. That is, they are focused on the manner through which participants perceive, visualize or characterise some features of reality. Memories, social representations, categories, attitudes, beliefs, stereotypes, prototypes, and schemata have this characteristic. For the cognitivist, the interest is primarily in how mental processes of one kind or another transform people's perception and understanding of the world and influence subsequent action. The dominant assumption guiding psychological theorizing is not merely cognitivism - it is perceptual-cognitivism: our cognitive constructions of reality are taken to be based in perception, and perception in some shape or form provides a way of grounding cognitive processes in reality (e.g. Neisser, 1976; Shaver, 1983).

In contrast, discursive psychology is concerned with how representations are constructed within, and constitutive of, social practices. Take memory or remembering, for example. One theme in discursive psychology is the way reports of past events are constructed to 
perform particular acts such as blamings or excuses (Edwards et al., 1992). A major reason for describing something that happened in the past is that there is some issue at stake. The following example is from a rape trial (Drew, 1990 - see also, Wooffitt, 1990 on the same material). The counsel for the defence (C) is examining the central prosecution witness (W), the victim of the alleged rape.

\section{$\mathrm{C}: \quad$ [referring to a club where the defendant and the victim met] it's where girls and fellas meet isn't it?}

W: People go there.

Both the Counsel and the Witness produce versions of the activities that take place in the club. These are not formally contradictory - yet these versions can be the basis for different inferences on the part of the jury. In particular, the Counsel's description "it's where girls and fellas meet" gives an impression of the intentions and expectations the clientele might have of one another which is a commonplace of rape defences. The Witness' alternative, "people go there", neutralizes these implications. The adequacy or generality of this analysis is not the issue here; its point is to show the way remembering can be reconceptualized in terms of discursive constructions of reality that are parts of social actions (DAM Point Two).

We can illustrate three further themes in discursive psychology using this example. First, it shows how we can make sense of other psychological notions in discursive terms. One of the main features of the discourse in this passage is that it relates to the central legal issue: what is the responsibility of the defendant for the crime? Looked at in common psychological parlance a court case is an arena for attribution. Indeed, in many respects memory and attribution are two sides of the same coin. A memory can be constructed in talk precisely for 
the inferences it makes available about the responsibility of various parties (Edwards and Potter, 1992; cf. Bogen and Lynch, 1989). However, it is important to emphasise that when we are referring to attribution here we are reconstructing it in terms of discursive practices for the allocation of responsibility and blame and not wishing to buy into the customary attributional ontology of mental heuristics and processes (Edwards and Potter, 1992b).

A second theme illustrated in this brief extract is the use of categorizations: "girls", "fellas", "people". Again, rather than look at these as merely traces of underlying cognitive structures we can analyse their interactional deployment. For example, much of the effect of the Counsel's version derives from its use of the categories "girls" and "fellas", which not only establish gender as a relevant concern but imply a particular style of relationship. Constructing a sexual motive for the victim is the basis for an attack on her credibility. Alternative categorizations such as 'men and women', 'girls and boys' would not do the same job. The Counsel's categorizations contrast to the gender and age neutral category "people" used by the Witness. There is a growing body of research in conversation and discourse analysis which has been concerned precisely with the role of categories in social practices (e.g. Coulter, 1991; Edwards, 1991; Jayyusi, 1984; Potter and Reicher, 1987; Sacks, 1974; Watson, 1983).

The third theme illustrated by our court-room example is that activities are often, perhaps overwhelmingly, done as parts of interaction sequences involving other people (DAM Point Three). These are generally interpersonal or intergroup issues involving blame, responsibility, compliment, reward, request, invitation and so on. It is action in sequence rather than isolated individual acts that are the primary focus of discursive psychology. This kind of point has been well made in critiques of speech act theory by conversation analysts 
(Levinson, 1983: 356-64; Schegloff, 1988). It has a particular methodological significance for psychologists and communication researchers who use content analysis in ways which almost inevitably cut across the sequential structures of interaction (see Edwards and Potter, 1992b; Potter and Wetherell, 1987).

\section{$\underline{\text { Fact and Interest }}$}

Up to now in this chapter we have placed a lot of emphasis on the role of versions in people's everyday practices. This raises the question of why people should conduct activities indirectly via versions rather than through more direct means. Why, for example, does the Counsel in the trial extract above embed implications about the Witness's reasons for visiting the club in a version of its nature, rather than making the suggestions more explicitly? A variety of motivations are potentially at work here. However, we have been particularly interested in the way participants can use versions to manage what we have called the dilemma of stake or interest (DAM Point Four).

One of the features of interaction between people and groups is that they are commonly taken as entities with desires, motives, institutional allegiances and so on. That is, they are taken as entities with a personal or institutional stake or interest in their actions. The referencing of such a stake is one principal way of discounting the significance of an action or reworking its nature. For example, a blaming can be discounted as merely a product of spite; an offer may be discounted as an attempt to influence. In the trial example above, the institutionalized roles of the Defence Counsel and the principal Witness provide resources for discounting their claims or the significance of their versions. 
There is no single way to manage this dilemma. Yet research has started to explore in some detail the way people use reports, descriptions or versions to this end (cf. Pomerantz, 1984b). A sensitive action such as a blaming or a request can be accomplished by providing an ostensibly disinterested factual report (Drew, 1984). This allows the recipient, or important others such as the jury, to follow through the implications rather than have the speaker or writer formulate them explicitly (cf. Wowk, 1984).

This perspective on the role of ostensibly factual versions has important implications for the way we construe traditional psychological notions such as attitudes and, more specifically, prejudice and discrimination. Attitudes are treated by psychologists as evaluative positions held by people. As such they are taken to be features of individual psychology rather than features of the world. Yet, if we look at the issue of evaluation from the point of view of participants, things look rather more complicated. The speaker of attitudes is caught in the dilemma of interest; that is, their attitudes may be treated as having psychological motivations that are the subject of censure of some kind (Potter and Wetherell, 1988). This is potentially the case with any attitudes; however, it is a particular risk with attitudes to minority groups, for such attitude expressions may be construed as discriminatory and a product of prejudice. This is, of course, one motivation for the familiar disclaimer structure: 'I'm not racist but...' (van Dijk, 1987, 1992). This 'reading through' attitudes to motives is both an everyday practice done by participants and a technical practice done by social psychologists (Billig, 1988; Wetherell and Potter, 1992). Each depends on referring attitudes back to individual psychology. One of the features of discursive psychology, with its emphasis on everyday practices, is that we can start to reflexively explore the complex relationships between the 
common sense of people and psychologists. Indeed, DAM could be used on the discourse of psychologists or even this papers in this current collection (cf. Ashmore, 1989).

The virtue of managing negative evaluations via factual versions is that the evaluation becomes a feature of the world rather than a feature of the speaker's own psychology. A version can display what is bad, or good, as lying 'out-there' in some features of reality, as nothing to do with them, not something that they wanted or even something that they derived satisfaction from. The simple technical division between facts and attitudes fails to do justice to everyday settings where the danger of being interpreted as 'having an attitude' may be precisely the motivation for constructing a factual version. Within discursive psychology, the focus is changed from attitudes as mentally encoded, potentially enduring positions, to the practices through which evaluation is conducted and evaluative positions attributed (Billig, 1989, 1991b; Maynard, 1989, 1991; Pomerantz, 1984a; Potter and Wetherell, 1988; Wetherell and Potter, 1992).

Once we see the importance of factual versions in these central social practices another important field of study comes to the fore. To successfully manage the dilemma of stake or interest via a factual version it is necessary to produce a version that can actually be accepted as factual, or at least one which is rhetorically organized in such a manner that it is difficult to undermine or rebut. Thus we can study the procedures that people use to construct their versions as 'factual'; that is, external to the speaker and their desires and concerns (DAM Point Five). How, in other words, are factual accounts given out-there-ness (Smith, 1990; Wooffitt, 1992; Woolgar, 1988)? 
This is not the place to review the growing body of research on this topic (see Edwards and Potter, 1992a). However, one example will give a flavour of what is being suggested here, as well as indicating a further reworking of the psychological notion of categories. One way of warranting a version as factual is to work on the category entitlement of the speaker (Coulter, 1991; Jayyusi, 1984; Sacks, 1974). Certain category memberships warrant, in themselves, certain sorts of knowledge. For example, doctors are often treated as knowledgeable about illness; or when an 'ordinary caller' phones the emergency switchboard to report a disturbance they are asked how they know and their grounds may be interrogated; yet the head of security at the Greyhound depot is treated as entitled to know - their report is not queried (Whalen and Zimmerman, 1990).

Categories like this are relatively agreed and socially stable, although they may be exploited in subtle and unexpected ways. However, a particularly interesting category entitlement is that to knowledge which any person is expected to know: how they are feeling, where it hurts, what their intentions are with respect to a shopping trip (Sacks, 1989). This means that psychological reports are produced against a background of these entitlements, and can be examined as such. Put another way, deviations from such expectations can be treated as an accountable matter. Discursive psychologists can study how these entitlements are constructed and occasioned, perhaps in ways which draw attention to, or attempt to rework these 'anyperson' entitlements. For example, we can study the rhetorical work engaged in by John Dean in his Watergate testimony against expectations about what anybody would be entitled to be able to recall (Edwards and Potter, 1992c).

A further example of the exploitation of category entitlement appears in reports of crowd violence by media and political sources. One common warranting technique in media 
accounts of crowd events is to characterize the informant as a 'community leader'. This has twin rhetorical advantages. First, such category members are widely treated as knowledgeable about their community. Second, 'community leader' is a category membership with no formal credentials; nor can it be warranted perceptually (as with 'redhead'); it depends on the person doing particular activities and having community assent - things which are hard to clearly specify. As a consequence this is a categorization whose fuzziness can be put to rhetorical work - in that it is particularly hard to undermine (Potter and Halliday, 1990).

The final part of the fact and interest section of our model is the emphasis on factual versions being rhetorically organized to counter alternatives (DAM Point Six). The point here is that a common feature of the use of versions to perform actions is that the versions are organized to undermine some known or commonplace alternative; that is, they are designed rhetorically. The rape trial extract we used above is a clear and compact illustration of this. The versions "it's where girls and fellas meet" and "people go there" are rhetorically counterposed: the latter undermines inferences that might be made on the basis of the former. However, the rhetorical design of versions is not something confined to face to face talks, nor to obviously adversarial situations such as court cases.

The discursive model highlights the way participants orientate to disputes and conflicts of interests on a range of different levels, lending to the production of rhetorically designed versions. For example, Billig (1991; cf Billig et al., 1988) argues that expressions of attitudes should be understood rhetorically, for the requirement to manifest an attitude appears precisely when there is a range of available alternatives which may be argued over. Indeed, attitude questionnaires incorporate such ideas, being built up from Likert items which are often parts of commonplace argumentative positions. And the typical strongly 
agree/disagree dimension offered is itself argumentative. Unfortunately, although attitude scales are produced in this way they are often interpreted as if they were recording a person's opinions in the abstract (Potter and Wetherell, 1987).

\section{Accountability}

In the final section of our model we emphasize the various ways in which participants deal with accountability in their discourse. Attribution theory has devoted a good deal of energy to illuminating some of the ways in which accountability is treated in reported events (DAM Point Seven). However, it has overwhelmingly dealt with this from the point of view of the recipient: given some event, how do people understand the pattern of responsibility? And, as we noted above, it has conflated text and reality to a confusing degree. The discursive model spotlights the equally important issue of how a version of some event is constructed to imply responsibility (DAM Point Eight). We have found it heuristically useful to distinguish two levels of accountability: that in the reported event and also that of the current speaker who is making the report. And we have started to explore the relation between these levels, such that current responsibility in producing versions can allow inferences about responsibility in some past event, while a version of responsibility in some past even can allow inferences about current responsibility (DAM Point Nine).

Take, for example, the following extract from a television interview with the then British Prime Minister, Margaret Thatcher, about the resignation of her Chancellor, Nigel Lawson. 
Thatcher. I tried very hard to dissuade the Chancellor from going (.2) .hh but he had made up his mind and in the end I had to accept his resignation and appoint someone else.

This extract could, with a bit of effort perhaps, be read as a mere description: a neutral telling of the facts of some past events. However, it follows a question about whether she is to blame for the resignation; in this context we can see that the description is designed to display her lack of blame and, more broadly, her current competence to head the government. That is, the description is offered, and offered in the specific way it is, to attend to the current activities of blame and mitigation. Indeed, we suggest that speakers' concern with their own accountability is likely, in most cases, to be paramount, and therefore versions in which responsibility is assigned to persons, groups or events are generally likely to have this inferential relationship to the actions of the current speaker.

The pervasiveness of this inferential relationship between the construction of responsibility and causality in versions of events and the accountability of the current speaker for the actions done in talking about them is one of the reasons why it is important for people to be able to mark what Goffman (1981; cf. Levinson, 1988) calls 'footing'; that is, the ability to mark when a person is speaking 'for herself' or, in contrast, reporting the speech of another. Indeed, such distinctions can become quite complicated: one can be reporting the views of someone as rendered into talk by another; and there are various possible roles for being the recipient of the speech (e.g. addressed vs unaddressed, overhearer vs eavesdropper). The point is that an elaborate system of this kind becomes necessary so that the speaker can manage inferences about their own accountability when they are making descriptions. Marking the footing for 
the description is a way of indicating who should be held accountable for any inferences that might flow (see also Clayman, forthcoming).

It is important to emphasize that we are not treating footing as something separate from the constructive and rhetorical processes which we discussed in the Fact and Interest section of our model. In a sense, the construction of footing is just one more arena of factual accounting: footing may be an attempt to warrant a version by attributing it to a member of a category with particular entitlements to knowledge (as in the example of 'community leaders' - Potter and Halliday, 1990); or it can be an attempt to draw on potentially problematic claims in the course of an argument while avoiding the noxious attributions that might be made to a supporter of those claims (as when a speaker reports 'ideas put out' about the prevalence of rape in a minority group as part of critique of immigration - Potter and Wetherell, 1988). Looked at from another direction, footing and accountability is a further way of understanding the importance of techniques of fact construction. Such techniques are a way of producing reports which originate outside of the interests and desires of the speaker. Indeed, the 'empiricist discourse' of science (Gilbert and Mulkay, 1984) has taken this process to its logical conclusion where the scientist is merely reporting what the data or research finding 'says' or 'shows'.

More generally, when we examine the argumentative patterns in ordinary discourse we do not find the neat organization which might be expected from a person working from a consistent set of beliefs and attitudes, or a unitary 'knowledge base'. Rather what we see is a fragmentation - Billig calls it the 'kaleidoscope of common sense' - where explanans and explanandum regularly swap places (Billig, 1991b), where shifts are fluidly made between arguments from principle and practice (Litton and Potter, 1985; Wetherell et al., 1987) and 
where 'liberal and egalitarian values' are selectively drawn on and reworked, sometimes to racist and authoritarian effect (Wetherell and Potter, 1992). This has an important methodological consequence: we are unlikely to get at the workings of social practices through identifying particular tropes, coding and counting them. These studies emphasise again that these things must be examined in context for their specific construction, their sequential placement and rhetorical organization.

\section{$\underline{\text { Facts, Descriptions and Discursive Psychology }}$}

At this point it is important to make some qualifications. We are not offering this as a complete model of discourse processes, nor as one which is finished even for the particular domain we have been most concerned with, namely the use of descriptions in activity sequences. What we have tried to do is identify some links between what have previously been considered to be somewhat disparate areas of psychological investigation and to make some preliminary suggestions as to how a swathe of psychological concepts can be reworked in discursive terms. So far sustained work has been conducted on the theoretical notions of attitudes, attribution, categories, gender, memories/remembering, self, personality and identity, and social representations. One of the aims of the discursive action model is to start to map organized links between these different lines of work. At the same time we are not suggesting that psychologists or communication workers must abandon using these concepts in their more traditional ways - after all, they are well suited for many questions and issues.

It is also important to stress that although, for the purpose of our exposition, we have taken the model in sequential stages we are not suggesting that research should be organized in this 
way. On the contrary, much of the time research will be concerned with issues where a number of different features of the model will be relevant simultaneously. Indeed, it is, for example, almost impossible to seriously consider fact construction without paying close attention to the relevant concerns with rhetorical alternatives and current accountability. Research should be sensitive to the particulars of the discursive practice rather than to the categories of the model. More generally, one of the features of the perspective developed by discourse analysts has been a recognition of the flexibility of participants' talk and writing when accomplishing particular actions. That is not to say that there is not pattern and organization; however, it is often organization of variation: the same activity can be done in numerous different ways, drawing on different discursive resources.

One of the most important features of this model with respect to alternative schemes for understanding human conduct developed across psychology is that it rejects the commonly presupposed contrast between the factual realm and the psychological realm of attitudes and evaluations. Rather than seeing facts as marking the edge to psychological interest because they are simply reflections of the way the world is we can see that this idea is, itself, part of a move in a social practice. The 'out-there-ness', world reflecting, nature of facts is precisely what makes them powerful tools for doing particular actions. Moreover, the presence of factual versions in everyday discourse is by no means a sign that the charged world of human affairs is giving way to the cold logic of reality. On the contrary, reports, versions, factual descriptions are often drawn on precisely when there are a sensitive or problematic issue at stake. Latour (1987) shows with the example of scientific dispute that when disputation gets hot, description gets technical; we suggest the same is often true in everyday talk. 
Perhaps the most immediate application of this model is to throw new light on the way activity is organized in institutional and semi-institutional settings. Our own most developed work with it has been on political controversies (Edwards and Potter, 1992a). However, we are starting to consider its utility in situations involving counselling, classroom management, and the interaction between social workers and clients. In these cases, the relatively stable and restricted constellations of stake and outcome provide a heuristic way in to analysis. Nevertheless, it will be important to explore the model in settings involving unconstrained everyday talk which are, arguably, the most fundamental (cf Heritage, 1984).

In our view, the most productive line of future development will involve studies of naturalistic records of interaction - people doing what they would do normally, captured on tape and subsequently transcribed. These allow the analyst to consider activities in their sequential context and, at the same time, they accommodate the subtlety of participants' orientations to stake and interest. We have already noted that we see severe problems in using content analytic techniques on such materials. We are also sceptical of the possibility of effective experiments: they are better suited to causal rather than rhetorical relations; they tend to involve a considerable amount of predefinition of categories, and they are arenas where it is difficult to duplicate the sorts of delicate interests that people orientate to in everyday settings. This is not to say that inventive experimentation might not have a role in the development of theory in this area; however, we suspect it is more likely that the DAM model will be able to throw light on the operation of experiments than the other way round. 


\section{$\underline{\text { References }}$}

Ashmore, M. (1989) The Reflexive Thesis: Wrighting Sociology of Scientific Knowledge. Chicago: University of Chicago Press.

Atkinson, J.M. and Heritage, J. (Eds.) (1984) Structures of Social Action: Studies in Conversation Analysis. Cambridge: Cambridge University Press.

Billig, M. (1987). Arguing and Thinking: a Rhetorical Approach to Social Psychology. Cambridge: Cambridge University Press.

Billig, M. (1988). Rhetorical and historical aspects of attitudes: the case of the British monarchy. Philosophical Psychology, 1, 83-103.

Billig, M. (1989) The argumentative nature of holding strong views: A case study. European Journal of Social Psychology, 19, 203-23.

Billig, M. (1991) Ideologies and Opinions. London: Sage.

Billig, M. (1992) Talking about the Royal Family. London: Routledge.

Billig, M., Condor, S., Edwards, D., Gane, M., Middleton, D.J. \& Radley, A.R. (1988). Ideological Dilemmas: a social psychology of everyday thinking. London: Sage.

Bogen, D. and Lynch, M. (1989) Taking account of the hostile native: plausible deniability and the production of conventional history in the Iran-Contra hearings. Social Problems, 36, 197-224.

Clayman, S.E. (forthcoming) Footing in the achievement of neutrality: The case of news interview discourse. In P. Drew and J. Heritage (Eds) Talk at Work. Cambridge: Cambridge University Press.

Coulter, J. (1979) The Social Construction of Mind. London: Macmillan.

Coulter, J. (1989). Mind In Action. Oxford: Polity. 
Coulter, J. (1991). Logic. In G. Button (Ed.) Ethnomethodology and the Human Sciences. Cambridge; Cambridge University Press.

Coulthard, M. and Montgomery, M. (Eds.)(1981) Studies in Discourse Analysis. London; Routledge and Kegan Paul.

Drew, P. (1984) Speakers' reportings in invitation sequences. In J.M. Atkinson and J.C. Heritage (Eds.) Structures of Social Action: Studies in Conversation Analysis. Cambridge: Cambridge University Press.

Drew, P. (1990) Strategies in the contest between lawyers and witnesses. In J.N. Levi and A.G. Walker (Eds.) Language in the Judicial Process. New York: Plenum.

Edwards, D. (1991) Categories are for talking: On the cognitive and discursive bases of categorization. Theory and psychology, 1, 515-42.

Edwards, D. and Potter, J. (1992a) Discursive Psychology. London; Sage.

Edwards, D. and Potter, J. (1992b) Language and causation: A discursive action model of description and attribution, Psychological Review, *,**-**.

Edwards, D. and Potter, J. (1992c) The chancellor's memory: rhetoric and truth in discursive remembering. Applied Cognitive Psychology, *,**_**.

Edwards, D., Middleton, D. \& Potter, J. (1992) Toward a discursive psychology of remembering. The Psychologist, *, *****.

Foucault, M. (1971) 'Orders of Discourse', Social Science Information, 10: 7-30.

Gergen, K.J. (1985). The social constructionist movement in modern psychology. American Psychologist, 40, 266-75.

Gilbert, G. N. and M. Mulkay (1984) Opening Pandora's Box: a Sociological Analysis of Scientists' Discourse. Cambridge: Cambridge University Press.

Goffman, E. (1981) Forms of Talk. Oxford: Basil Blackwell.

Harré, R. (1983) Personal Being: A Theory for Individual Psychology. Oxford: Blackwell. 
Heritage, J. \& Watson, D.R. (1979) Formulations as conversational objects. In G. Psathas (Ed.), Everyday Language: Studies in Ethnomethodology. New York: Irvington. Heritage, J. (1984) Garfinkel and Ethnomethodology. Cambridge: Polity.

Heritage, J. (1990/91) Intention, meaning and strategy: Observations on constraints on interaction analysis, Research on Language and Social Interaction, 24, 311-32.

Jayyusi, L. (1984) Categories and the Moral Order. London: Routledge and Kegan Paul.

Kruglanski, A. (1990) Lay epistemic theory in social-cognitive psychology, Psychological Inquiry, 1, 202-46.

Kuhn, T.S. (1970) The Structure of Scientific Revolutions, 2nd edition. Chicago: University of Chicago Press.

Latour, B. (1987) Science in Action. Milton Keynes: Open University Press.

Levinson, S.C. (1983). Pragmatics. Cambridge: Cambridge University Press.

Levinson, S.C. (1988). Putting linguistics on a proper footing: explorations in Goffman's concepts of participation. In P. Drew and A. Wootton (Eds.), Erving Goffman: Studies in the Interactional Order. Cambridge: Polity.

Litton, I. and Potter, J. (1985) Social representations in the ordinary explanation of a 'riot', European Journal of Social Psychology, 15, 371-88.

Maynard, D.W. (1989) Perspective-display sequences in conversation, Western Journal of Speech Communication, 53, 91-113.

Maynard, D.W. (1991) The perspective-display series and the delivery and receipt of diagnostic news. In Boden, D. and Zimmerman, D. (Eds) Talk and Social Structure. London; Polity.

Mills, C.W. (1940) Situated actions and vocabularies of motive. American Sociological Review, 5: 904-13. 
Moscovici, S. (1984) The phenomenon of social representations. In R.M. Farr and S.

Moscovici (eds), Social Representations. Cambridge: Cambridge University Press.

Neisser, U. (1976). 'General, academic and artificial intelligence.' In L.B. Resnick (Ed), The Nature of Intelligence. New York: Lawrence Erlbaum Associates.

Peräkylä, A. and Silverman, D. (1991) Owning experience: describing the experience of other persons, Text, 11, 441-80.

Pomerantz, A. (1980). Telling my side: 'limited access' as a fishing device. Sociological Inquiry, 50, 186-198.

Pomerantz, A. (1984a) Agreeing and disagreeing with assessments: some features of preferred/dispreferred turn shapes. In J.M. Atkinson and J. Heritage (Eds.), Structures of Social Action: Studies in Conversation Analysis. Cambridge: Cambridge University Press.

Pomerantz, A. (1984b) Giving a source or basis: The practice in conversation of telling 'how I know'. Journal of Pragmatics, 8, 607-625.

Pomerantz, A. (1987) Descriptions in legal settings. In G. Button and J.R.E. Lee (Eds.), Talk and Social Organization. Clevedon: Multilingual Matters.

Popper, K. (1959) The Logic of Scientific Discovery. London: Hutchinson.

Potter, J. and Edwards, D. (1990) Nigel Lawson's tent: Discourse analysis, attribution theory and the social psychology of fact. European Journal of Social Psychology, 20, 40-24.

Potter, J. and Halliday, Q. (1990) Community leaders as a device for warranting versions of crowd events, Journal of Pragmatics, 14, 725-41.

Potter, J. and Reicher, S. (1987) 'Discourses of community and conflict: The organization of social categories in accounts of a 'riot", British Journal of Social Psychology, 26, 2540. 
Potter, J. and Wetherell, M. (1987) Discourse and Social Psychology: Beyond Attitudes and Behaviour. London: Sage.

Potter, J. and Wetherell, M. (1988) Accomplishing attitudes: Fact and evaluation in racist discourse. Text, 8, 51-68.

Sacks, H. (1974) On the Analyzability of Stories by Children. In R. Turner (ed.), Ethnomethodology. Harmondsworth: Penguin.

Sacks, H. (1989) Lecture Five: Suicide as a device for discovering if anybody cares, Human Studies, 12, 261-70.

Schegloff, E.A. (1972) Notes on a conversational practice: Formulating place. In D. Sudnow (Ed.), Studies in Social Interaction. Glencoe: Free Press.

Schegloff, E.A. (1988) Presequences and indirection: applying speech act theory to ordinary conversation. Journal of Pragmatics, 12, 55-62.

Shaver, K.G. (1983) An Introduction to Attribution Processes. Hillsdale, NJ: Lawrence Erlbaum.

Smith, D. (1990) Texts, Facts and Femininity: Exploring the relations of ruling. London; Routledge.

van Dijk, T.A (1987) Communicating Racism: Ethnic Prejudice in Thought and Talk. London: Sage.

van Dijk, T.A. (1992) Discourse and the denial of racism, Discourse and Society 3, 87-118. van Dijk, T.A. and W. Kintch (1983) Strategies of Discourse Comprehension. London: Academic Press.

Watson, R. (1983). The presentation of victim and motive in discourse: The case of police interrogations and interviews. Victimology, 8, 31-52. 
Wetherell, M. and Potter, J. (1988) Discourse analysis and the identification of interpretative repertoires. In C. Antaki (Ed.), Analysing Everyday Explanation: a Casebook of Methods. London: Sage.

Wetherell, M. and Potter, J. (1989). Narrative characters and accounting for violence. In J. Shotter and K. Gergen (Eds.), Texts of Identity. London: Sage.

Wetherell, M. and Potter, J. (1992) Mapping the Language of Racism: Discourse and the Legitimation of Exploitation. Hemel Hempstead; Harvester/Wheatsheaf.

Wetherell, M., Stiven, H. and Potter, J. (1987) Unequal egalitarianism: A preliminary study of discourses concerning gender and employment opportunities, British Journal of Social Psychology, 26, 59-72.

Whalen, M.R. and Zimmerman, D.H. (1990) Describing trouble: Practical epistemology in citizen calls to the police. Language in Society, 19, 465-92.

Wittgenstein, L. (1953) Philosophical Investigations. Oxford; Blackwell.

Wooffitt, R.C. (1990) On the analysis of interaction: an introduction to conversation analysis. In P. Luff, D. Frohlich and G.N. Gilbert (Eds.), Computers and Conversation. New York: Academic Press.

Wooffitt, R.C. (1992) Telling Tales of the Unexpected: The organization of factual accounts. Hemel Hempstead; Harvester/Wheatsheaf.

Woolgar, S. (1988). Science: the very idea. Chichester: Ellis Horwood./ London: Tavistock.

Wowk, M. (1984) Blame allocation: Sex and gender in a murder interrogation. Women's Studies International Forum, 7, 75-82. 